\title{
CORPORATE SOCIAL RESPONSIBILITY (CSR) PT. ANEKA TAMBANG UBPE SEBAGAI SOLUSI MASALAH PENDIDIKAN BAGI MASYARAKAT KECAMATAN NANGGUNG, KABUPATEN BOGOR
}

\author{
Danis Dea Rizky, Santoso Tri Raharjo, Risna Resnawaty \\ deadanis@gmail.com, santosotriraharjo@gmail.com, happytruz@yahoo.com
}

\begin{abstract}
ABSTRAK
Penelitian ini dilatarbelakangi oleh munculnya isu mengenai rendahnya pendidikan yang dialami oleh masyarakat kabupaten Bogor. Dilihat dari kondisi wilayah kabupaten Bogor pada bidang pendidikan, yaitu mengalami kerusakan fasilitas gedung sekolah, minimnya jumlah guru yang berstatus PNS, dan berpengaruh pada siswa menerima pelajaran yang tidak efektif. Permasalahan yang dihadapi kabupaten Bogor di bidang pendidikan ini tercermin dari ukuran Indeks Pembangunan Manusia (IPM) pada tahun 1999. Dilihat dari hasil ukuran IPM tahun 1999 beberapa kecamatan yang ada di kabupaten Bogor yaitu salah satunya kecamatan Nanggung cengan kondisi masyarakat tertinggal, pendapatan rendah, serta hubungan antar daerah tidak lancar atau terisolasi. Dilihat isu tersebut selain pemerintah yang dapat membantu meningkatkan kualitas pendidikan di wilayah kecamatan Nanggung maka perlu peran swasta melalui Corporate Social Responsibilit (CSR).PT. Antam UPBE Pongkor ikut berkontribusi dalam meningkatkan kualitas pendidikan di wilayah operasi pertambangan melalui program CSR nya, yaitu pemberian bantuan guru honorer, siswa berprestasi, dan perbaikan sarana prasarana sekolah. Adanya program CSR yang dilakukan oleh PT. Antam UPBE akan membantu peningkatkan mata pencaharian masyarakat dan menciptakan kondisi kehidupan yang berkelanjutan.

Kata kunci: Pekerjaan Sosial Industri, Corporate Social Responsibility (CSR), Community

Development.
\end{abstract}

\section{ABSTRACT}

Research was triggered by the emergence of the issues concerning the low level of education that is experienced by people bogor regency. Seen from the condition of bogor regency the education sector, namely the school building, damaged facility " the lack of status pns, the number of teachers and influential on the kids accept the lessons that are not effective.The problems faced by bogor regency in the education sector is reflected in the size of the human development index (IPM) in 1999. Seen from the results of the size of ipm 1999 some sub-districts in the county of bogor sub-district is one of them is left behind, nanggung cengan condition of a community low incomes, and of inter-regional relation not smooth or isolated.Seen the issue in addition to the government that can help improve the quality of education in the sub-district nanggung should be the role of private sector through corporate social responsibilit (CSR). PT. Antam UBPE Pongkor to contribute to improve the quality of education in the region of operation of mines through csr its, namely aid permanent teachers, students, and improved infrastructure of school. The presence of CSR done by PT.Antam UBPE will help increase livelihood society and create sustainable conditions of life.

Keywords: social work industry, corporate social responsibility (csr), community development 


\section{PENDAHULUAN}

Pendidikan merupakan hal terpenting dalam kehidupan manusia, karena melalui pendidikan dapat membentuk manusia yang berkualitas dan mampu bertahan hidup dalam menghadapi era globalisasi seperti sekarang ini. Pendidikan membentuk dasar manusia berkaitan dalam pertumbuhan ekonomi, sosial, politik, dan perkembangan masyarakat pada umumnya. Pendidikan pertama kali yang kita dapatkan di lingkungan keluarga, lingkungan sekolah dan lingkungan masyarakat.

Dilihat dari kondisi wilayah Kabupaten Bogor pada bidang pendidikan salah satunya mengalami kerusakan fasilitas gedung sekolah yang kondisinya hampir merata, sehingga dengan fasilitas gedung terbatas para siswa menerima pelajaran tidak memuaskan karena terjadi kekhawatiran apabila fasilitas gedung tiba-tiba mengalami ambruk. Selain itu, minimnya jumlah guru yang berstatus PNS turut menjadi persoalan dalam pelaksanaan proses belajar mengajar. Sehingga dengan minimnya jumlah guru mengakibatkan para siswa menerima pelajaran tidak efektif dikarenakan sistem belajar mengajar dilakukan dalam satu ruangan. Kondisi demikian proses pendidikan tidak mencapai hasil yang optimal terutama pada siswa-siswi. Hal ini perlu adanya antisipasi yang dilakukan oleh Pemerintah untuk meningkatkan kualitas pendidikan yang lebih baik. (Sumber: diakses pada http://www.ombudsman.go.id).

Permasalahan yang dihadapi kabupaten Bogor di bidang pendidikan ini tercermin dari ukuran Indeks Pembangunan Manusia (IPM). IPM pada tahun 1999 mencapai $66,6 \%$ dilihat dari Pencapaian Angka Melek Huruf (AMH) penduduk sebesar 93,7\%, Angka Harapan Hidup sebesar $65,2 \%$ dan Rata-rata Lama Sekolah 8,0\%. Dilihat dari hasil ukuran Indeks Pembangunan Manusia (IPM) tahun 1999 di Kabupaten Bogor masih mengalami minimnya kualitas pendidikan, pada kenyataannya beberapa kecamatan yang ada di kabupaten Bogor salah satunya yaitu kecamatan Nanggung merupakan salah satu kecamatan dengan kondisi pendidikan rendah. Kondisi masyarakat di kecamatan ini termasuk dalam kategori tertinggal, berpendapatan rendah, serta hubungan antara daerah tidak lancar atau terisolasi (Setyaningsih, 2005).

Kondisi masyarakat yang masih memiliki pendapatan rendah, terutama keluarga yang masih mengalami kesulitan dalam menyekolahkan anak-anaknya sehingga bagi mereka sekolah tidak dianjurkan. Keadaan kondisi masyarakat tersebut dalam memenuhi kebutuhan hidupnya memiliki bidang usaha yaitu bertani dan berdagang di mana sebagian masyarakat masih mengalami buta huruf. Dilihat dari karakteristik masyarakat yang telah dikemukakan tersebut, hal ini berdampak pada rendahnya pendidikan di Kecamatan Nanggung.

Mengenai kondisi pendidikan rendah di kecamatan Nanggung berakibat pengetahuan masyarakat minim, sulit memenuhi kebutuhan hidup, sulit berkembangnya mata pencaharian, kurangnya kesadaran sosial akan pentingnya pendidikan untuk perkembangan di masa yang akan datang, dan masyarakat masih menganut budaya tradisional.

Rendahnya pendidikan yang dialami kecamatan Nanggung tidak sesuai dengan cita-cita (Millennium Development Goals) MDG's di Indonesia dalam meningkatkan kualitas pendidikan. Hal ini menjadi kewajiban semua anak menerima pendidikan dasar sebagai tujuan MDG's di Indonesia untuk mewujudkan target meningkatkan kualitas pendidikan. Peningkatan angka partisipasi anak untuk bersekolah memang cukup berhasil, namun keberhasilan sesungguhnya dilihat ketika anak mendapatkan pendidikan dasar yang utuh. Disamping itu, sekolah juga dapat menimbulkan masalah jika tidak dapat memberikan sesuatu yang bernilai bagi anakanak misalnya tidak memiliki buku atau peralatan yang memadai serta bangunan fisik sekolah yang tidak layak digunakan. Selain itu kualitas pendidikan ditentukan oleh sumber daya manusia yang berkompeten. 
Dalam hal ini guru merupakan sumber daya manusia yang memiliki tugas utama untuk mendidik, mengajar, membimbing, mengarahkan, melatih, menilai, dan mengevaluasi peserta didik pada pendidikan anak usia dini jalur pendidikan formal, pendidikan dasar, dan pendidikan menengah (pada situs http://www.undp.or.id).

$$
\text { Pemerintah kabupaten Bogor }
$$

bertanggungjawab terhadap sekitar duapertiga pengeluaran publik untuk pendidikan, dengan demikian Pemerintah akan melakukan peningkatan kualitas pendidikan khususnya di kecamatan Nanggung yang masih mengalami rendahnya pendidikan. Namun, pengeluaran publik tersebut tidak mencakup kebutuhan dalam memenuhi peningkatan kualitas pendidikan maka diperlukan peran swasta melalui Corporate Social Responsibility (CSR).

PT. Antam UBPE Pongkor memiliki program Corporate Social Responsibility (CSR) dalam membantu menyelesaikan masalah sosial khususnya pada masalah pendidikan melalui program CSR PT. Antam UBPE berperan aktif dalam peningkatan kesejahteraan masyarakat sekitar melalui peningkatan kualitas pendidikannya. Demikian untuk mengatasi masalah pendidikan di daerah kecamatan Nanggung, pihak perusahaan melalui program Corporate Social Responsibility (CSR) telah memberikan bantuan guru honorer sebagai guru pengajar di sekolah, pemberian beasiswa berprestasi, dan perbaikan sarana prasarana sekolah. Dengan program CSR yang dilakukan oleh PT. Antam UBPE di Kecamatan Nanggung, masyarakat dapat memperoleh pendidikan dan pengetahuan yang lebih baik yang nantinya diharapkan dapat menghasilkan generasi produktif bagi masyarakat kecamatan Nanggung.

Dalam pelaksanaannya PT. Antam bekerja sama dengan UPTK Kecamatan Nanggung, Kabupaten Bogor dan masyarakat setempat. Program ini bertujuan untuk memberdayakan sumber daya manusia dalam menerima pengetahuan dan pendidikan yang lebih baik, meningkatkan kreatifitas para siswa di sekolah, mendorong para siswa untuk memiliki bekal dimasa yang akan datang, meningkatkan pola perilaku para siswa, serta memiliki cita-cita sebagai harapan anak bangsa.

Dalam upaya pemberian bantuan guru honorer, siswa berprestasi, dan didukung dengan perbaikan sarana prasarana yang lebih baik terdapat proses pelaksanaan dalam meningkatkan kemampuan masyarakat yang memiliki potensi terhadap pengembangan pendidikan. Pelaksanaan yang terdapat dalam program ini perencanaan, implementasi, monitoring dan evaluasi yang dilakukan oleh PT. Antam. Pelaksanaan kegiatan yang dilakukan oleh PT. Antam melibatkan UPTK Kecamatan Nanggung diharapkan terus berjalan sehingga mereka dapat mengembangkan pendidikan bagi siswa-siswi dan guru dengan penuh tanggung jawab.

Dengan rendahnya kualitas pendidikan yang dialami oleh masyarakat kecamatan Nanggung, maka penelitian ini penting untuk diteliti karena merupakan salah satu masalah yang menyangkut kesejahteraan hidup masyarakat. PT. Antam UBPE memiliki kontribusi dalam meningkatkan kualitas pendidikan melalui program CSRnya yaitu program pemberian bantuan guru honorer, siswa berprestasi, dan perbaikan sarana prasarana sekolah. Hal ini untuk meningkatkan kualitas pendidikan melalui program Corporate Social Responsibilit (CSR) PT. Antam UBPE Pongkor sebagai solusi masalah pendidikan bagi masyarakat Kecamatan Nanggung, Kabupaten Bogor.

\section{KAJIAN PUSTAKA}

Corporate Social Responsibility (CSR)

Beberapa definisi mengenai tanggung jawab sosial perusahaan atau Corporate Social Responsibilitu (CSR) yang dikemukakan oleh para ahli yang berbeda-beda, sesuai sudut pandang dan pemhaman yang berbeda mengenai CSR.Dalam hal ini perlu dikemukakan beberapa definisi sebagai pedoman dan pengantar kajian mengenai CSR. Berikut definisi CSR yang dikemukakan oleh Schermerhorn (1993) dalam buku Suharto, 2009: 102 yaitu: 
"Tanggungjawab Sosial Perusahaan (CSR) sebagai suatu kepedulian organisasi bisnis untuk bertindak dengan cara-cara mereka sendiri dalam melayani kepentingan organisasi dan kepentingan publik eksternal"

Lebih lanjut ISO 26000 mengenai Guidance on Social Responsibility juga memberikan definisi CSR. Meskipun pedoman CSR standard internasional ini baru diterapkan tahun 2010, draft pedoman ini bisa dijadikan rujukan. Menurut ISO 26000 (Suharto, 2009:104), CSR adalah :

"Tanggungjawab sebuah organisasi terhadap dampak-dampak dari keputusan-keputusan dan kegiatankegiatannya pada masyarakat dan lingkungan yang diwujudkan dalam bentuk perilaku transparan dan etis yang sejalan dengan pembangunan berkelanjutan dan kesejahteraan masyarakat; mempertimbangkan harapan pemangku kepentingan, sejalan dengan hukum yang ditetapkan dan norma-norma perilaku internasional; serta terintegrasi dengan organisasi secara menyeluruh" (Daft 3, 2007).

Definisi-definisi

tersebut menunjukkan adanya keragaman dalam mengartikan dan mengimplementasikan CSR, sehingga sampai saat ini tidak ada kesepakatan mengenai batasan tanggung jawab sosial perusahaan (McWilliams, et.al., dalam Radyati, M.R. \& Nindita. 2008). Namun demikian terdapat suatu pemahaman yang sama di masyarakat Eropa mengenai CSR dalam buku Raharjo, 2013: 28 sebagaimana pernyataan berikut :

"There is broad agreement in Europe on the definition of CSR as a concept whereby companies integrate social and environmental concerns - on a voluntary basis- into their business operations as well as their interactions with stakeholders"(European

\section{Communities 2007)}

Berdasarkan definisi-definisi tersebut dapat ditarik inti bahwa CSR merupakan di mana perusahaan mengintegrasikan sosial terhadap kepedulian organisasi bisnis dalam memenuhi kepentingan publik dengan carainteraksi para stakeholders dari dampak kegiatan-kegiatan usahanya pada lingkungan dan masyarakat, sehingga dapat meningkatkan kesejahteraan sosial dan menciptakan pembangunan yang berkelanjutan.

Community Development

Corporate Social Responsibility (CSR) merupakan salah satu bentuk tanggungjawab perusahaan kepada masyarakat sekitar untuk mengembangkan potensi yang ada pada masyarakat sehingga lebih maju dan sejahtera. Salah satu strategi yang digunakan dalam pelaksanaan CSR adalah melalui metode Community Development.

Community Development (pengembangan masyarakat) merupakan penyelesaian masalah dengan media masyarakat yang dalam pelaksanaannya memanfaatkan seluruh potensi masyarakat sehingga muncul kontribusi masyarakat untuk melakukan sebuah perubahan. Tujuan utama pendekatan Community Development membantu masyarakat agar memiliki kemampuan atau kapasitas untuk mampu mendorong dirinya sendiri. Budimanta (2003) mendefinisikan pemberdayaan masyarakat (Community Empowering) dalam lingkungan Community Development perusahaan sebagai program-program yang dilakukan berkaitan dengan pemberian akses yang lebih luas kepada masyarakat dalam menunjang kemandiriannya.

Karakteristik Community Development menurut David Harrison (1995):

1. Praktek Community Development memiliki fokus secara luas pada tujuan partisipasi masyarakat yang akan sangat berperan penting dalam keberhasilan pencapaian tujuan bersama.

2. Praktek Community Development meliputi penemuan tujuan-tujuan yang biasanya terdapat dalam masyarakat.

3. Praktek Community Development melibatkan organisasi dalam menolong anggota masyarakat dalam mengembangkan cara baru untuk menjaga keberfungsian organisasi. 
Pendekatan Community Development atau pengembangan masyarakat mendekati konsep empowerment dan sustainable development yang menjadi pijakan untuk mengukur keberhasilan program CSR. Perusahaan telah menyadari bahwa tanggungjawabnya bukan hanya berupa kegiatan ekonomi untuk menciptakan profit demi kelangsungan bisnisnya, melainkan juga tanggungjawab sosial (CSR) dan lingkungannya. Dengan kata lain perusahaan harus memiliki visi pengembangan masyarakat yaitu pemberdayaan masyarakat secara total, bekerjasama dengan stakeholder, agar mereka menjadi berdaya dan mandiri serta tumbuh menjadi agen perubahan sosial yang efektif di lingkungannya, baik ketika perusahaan beroperasi maupun pasca eksplorasi.

Pekerja sosial dapat dilihat perannya melalui tipe-tipe CD worker, CD worker tidak bisa mengambil keputusan secara keseluruhan tetapi harus mementingkan dan mengutamakan kebutuhan masyarakat.Oleh karena itu, CD worker harus mempunyai keterampilan dalam menganalisis, memiliki kesadaran, dan pengalaman sehingga mampu melakukan pemberdayaan pada masyarakat dengan tepat. Terdapat 4 (empat) tipe CD Worker, yaitu :

1. Adviser ; merupakan konsultan yang dituntut untuk bisa menghubungkan permasalahan antara faktor eksternal dan internal sehingga dapat mengetahui segala kondisi yang terdapat pada masyarakat.

2. Advokat; merupakan orang yang sangat memiliki kepedulian terhadap aspirasi atau keinginan masyarakat.

3. Planner ; merupakan pihak yang tidak langsung bersentuhan dengan masyarakat tetapi memiliki kemampuan dalam merancang dan merencanakan berbagai hal yang bersangkutan dengan sumber, proses, model, dan lain-lain.

4. Fill Agent; merupakan pihak yang ada dalam masyarakat yang dengan intens melakukan hubungan komunikasi dengan masyarakat. Seseorang fill agent menjadi pihak yang sangat penting untuk dilibatkan menjadi seorang pendamping karena lebih mengetahui kondisi dan karakteristik pada masyarakat.

Aspek terpenting dalam proses Community Development adalah melibatkan masyarakat itu sendiri. Keterlibatan ini tidak akan tercapai tanpa partisipasi penuh. Proses pengembangan masyarakat tidak dapat dipaksakan dari luar, dan tidak dapat ditentukan oleh pekerja masyarakat, dewan lokal atau departemen pemerintah. Proses pengembangan masyarakat harus menjadi proses masyarakat yang dimiliki, dikuasai dan dilangsungkan oleh mereka sendiri sehingga peningkatan kesadaran dalam pengembangan masyarakat menjadi bagian terpenting untuk menghasilkan perubahan yang diinginkan. Dalam buku CSR untuk Pemberdayaan Ekonomi Lokal Masyarakat (Indonesia Business Links) mengatakan bahwa dalam strategi perencanaan CSR terdapat tiga pendekatan untuk perencanaan CSR, yang disebut dengan tiga jenis Community Development Approach, yaitu:

a. Development for Community (Pengembangan untuk Komunitas)

Pencetus kegiatan CSR adalah perusahaan, yang mempunyai status sebagai pendonor, sedangkan kedudukan dari komunitas target adalah sebagai obyek dari kegiatan CSR. Tujuan dari CSR adalah mencapai suatu hasil akhir.Efek dari kegiatan CSR jenis ini adalah adanya ketergantungan dari komunitas terhadap perusahaan untuk mencapai hasil yang diinginkan.Oleh karena tujuan akhir adalah menghasilkan sesuatu, maka jangka waktu program relative pendek.CSR ini adalah berorientasi pada perusahaan (inkind).

b. Development with Community (Pengembangan bersama Masyarakat) Dalam program ini, kegiatan dirumuskan bersama-sama antara perusahaan dan masyarakat. Kedudukan perusahaan adalah sebagai agen pembangunan, sedangkan komunitas adalah sebagi subyek sekaligus obyek dari program CSR. Tujuan program CSR ini adalah 
berorientasi pada hasil dan memberikan sumbangan pada proses pembangunan. Dampak positif program adalah komunitas tidak sepenuhnya bergantung pada perusahaan, akan tetapi mereka dilatih untuk berswadaya. Jangka waktu program ini biasanya cukup lama dan berkelanjutan.Karakteristik program adalah berorientasi untuk memenuhi kebutuhan komunitas sekaligus tujuan perusahaan.

c. Development of Community (Mengembangkan Komunitas)

Karakteristik utama dari program ini adalah berorientasi pada pemenuhan kebutuhan komunitas.Tujuan akhirnya adalah pembangunan yang berproses.Disini yang menjadi pencetus ide adalah komunitas sendiri, jadi komunitas yang mengidentifikasi sendiri kebutuhan dan program.Dengan demikian komunitas berkedudukan sebagai subyek sedang perusahaan sebagai agen pembangunan.Dampak positifnya adalah membuat komunitas menjadi self-reliance oleh karena mereka terlibat langsung sepenuhnya pada program ini dan mereka sendiri yang menentukan keberhasilan atau kegagalan usahanya.Oleh karena itu, maka jangka waktunya panjang dan biasanya bentuknya dikenal dengan kemitraan, yakni pelatihan dan pendampingan.

\section{Pekerjaan Sosial Industri}

Menurut Suharto (2006b) definisi Pekerjaan Sosial Industri sebagai lapangan praktiks Pekerjaan Sosial yang secara khusus menangani kebutuhan-kebutuhan kemanusiaan dan sosial di dunia kerja melalui berbagai intervensi dan penerapan metoda pertolongan yang bertujuan untuk memelihara adaptasi optimal antara individu dan lingkungannya, terutama lingkungan kerja.

$$
\text { Pekerjaan Sosial Industri }
$$
menggunakan pengetahuan, keterampilan dan nilai-nilai pekerjaan sosial dalam pemberian pelayanan, program, dan kebijakan bagi para pegawai dan keluarganya, manajemen perusahaan, serikat-serikat buruhdan bahkan masyarakat yang berada di sekitar perusahaan.Sebagaimana dinyatakan akabas inti Pekerjaan Sosial meliputi kebijakan, perencanaan, dan pelayanan sosial pada persinggungan antara pekerjaan sosial dan dunia kerja. Di antara berbagai kegiatan Pekerjaan Sosial Industri antara lain adalah program bantuan (bagi) pegawai, promosi kesehatan, manajemen perawatan kesehatan, tindakan affirmative (pembelaan), penitipan anak, perawatan lanjut usia, pengembangan sumber daya manusia (SDM), pengembangan organisasi, pelatihan, dan pengembangan karir, konseling bagi penganggur atau yang terkena pemutusan hubungan kerja (PHK), tanggungjawab sosial perusahaan (corporate social responsibility), tunjangan-tunjangan pegawai, keamanan dan keselamatan kerja, pengembangan jabatan, perencanaan sebelum dan sesudah pension, serta bantuan pemindahan posisi kerja.

Konsep Pekerjaan Sosial Industri lebih luas daripada konsep Tanggungjawab Sosial Perusahaan (CSR) maupun Pengembangan Masyarakat (ComDev). Pekerjaan Sosial Industri mencakup pelayanan sosial yang bersifat internal dan eksternal. Hal ini CSR termasuk pada pelayanan eksternal Pekerjaan Sosial Industri.

\section{PEMBAHASAN}

Pendidikan merupakan terpenting bagi sumber daya manusia untuk dapat menjalani kehidupan yang lebih baik dari sebelumnya, khususnya bagi generasi muda menjalankan kehidupan di masa yang akan datang. Perkembangan zaman yang semakin pesat terjadinya perubahan sosial akan berpengaruh pada sikap dan kebiasaan masyarakat untuk mampu bertahan hidup dengan kondisi yang dinamis. Hal ini peran pemerintah sangatlah penting dalam membangun pendidikan bagi generasi muda dan peduli akan kualitas sumber daya manusia yang berkompeten 
sehingga dapat membangun bangsa Indonesia lebih maju.

Pemerintah sebagai peran utama dalam meningkatkan kualitas pendidikan akan tetapi tidak sepenuhnya pemerintah memberikan bantuan kepada masyarakat oleh sebab itu peran swasta yang dapat membantu pemerintah. Dengan demikian salah satu perusahaan yang berada di Kecamatan Nanggung, Kabupaten Bogor yaitu PT. Antam UBPE Pongkor yang memproduksi emas tentunya memiliki dampak positif maupun negatif terhadap lingkungan. Hal ini masyarakat Kecamatan Nanggung yang terdekat dengan kegiatan tambang dari PT. Antam maka perusahaan dapat mengatur pengolahan limbahnya agar tidak merugikan masyarakat. Masyarakat pun tidak ingin terganggu dengan kegiatan tambang dari perusahaan oleh karena itu PT. Antam sebagai sektor industri memiliki peran swasta melalui program Corporate Social Responsibility (CSR). Program CSR yang dilakukan oleh PT. Antam membantu menciptakan kondisi masyarakat yang lebih baik salah satunya program dalam bidang pendidikan. Kondisi wilayah terbilang pendidikan rendah berada di daerah pegunungan maka PT. Antam berkontribusi dalam bidang pendidikan untuk masyarakat Kecamatan Nanggung untuk menciptakan kualitas SDM yang lebih baik.

Corporate Social Responsibility (CSR) PT. Antam sebagai solusi masalah bagi masyarakat Kecamatan Nanggung, Kabupaten Bogor di mana kondisi wilayah pegunungan masyarakat tidak banyak mementingkan pendidikan hingga perguruan tinggi. Masyarakat yang cenderung lebih mementingkan kepada pekerjaan maka pola pikir anak-anak tidak peduli dengan kehidupan di masa yang akan datang. CSR ini yang mampu membuka pola pikir anak-anak agar mampu bertahan hidup di masa akan datang tentunya dengan perubahan sosial yang akan terjadi. Masalah pendidikan yang dialami masyarakat Kecamatan Nanggung, Kabupaten Bogor setidaknya dapat mengurangi permasalahan yang ada bahkan dapat menciptakan kondisi masyarakat yang kreatif dan sejahtera.

\section{DAFTAR PUSTAKA}

Laporan Akuntabilitas Kinerja Instansi Pemerintah Kabupaten Bogor. (2012).

Tersedia

:http://www.bogorkab.go.id/wpcontent/uploads/2013/12/Lakip-01.pdf

(Diakses Tanggal 15 Mei 2014, Pukul 12.30 WIB).

Mulyasari, Rini. (2013). Corporate Social Responsibility Oleh PT. East West Seed Indonesia. Jatinangor. Universitas Padjadjaran (Skripsi)

Raharjo, Santoso Tri. (2013). Relasi Dinamis Antara Perusahaan Dengan Masyarakat Lokal: Kajian Mengenai Kegiatan Tanggungjawab Sosial Industri Geothermal Kepada Masyarakat Lokal. UNPAD PRESS: Bandung.

Setyaningsih, Luluk dan Tun Susdiyanti.(2005). Persepsi Masyarakat Sekitar Terhadap Keberadaan PT. Antam Tbk Unit Bisnis Pertambangan Emas Pongkor. Universitas Nusa Bangsa. Tersedia: ejournal.kopertis4.or.id

Tanggal 25 April 2014).

Suharto, Edi. (2009). Pekerjaan Sosial Di

Dunia Industri: Memperkuat

Tanggungjawab Sosial Perusahaan". ALFABETA: Bandung.

--. (2003). Gambaran IPM Data

Basis.Tersedia :www.jabarprov.go.id (Diakses tanggal 29 Mei 201). 